Kristina Petrović

Iva Konc

Bojana M. Dinić ${ }^{1}$

Odsek za psihologiju

Filozofski fakultet

Univerzitet u Novom Sadu

Novi Sad, Srbija
UDK 159.9.072:616.89-008.441

Originalni naučni rad

https://doi.org/10.46630/gpsi.17.2020.01

\title{
PROVERA KONSTRUKT VALIDNOSTI SRPSKE ADAPTACIJE REVIDIRANE COLLETT-LESTER SKALE STRAHA OD SMRTI²
}

\begin{abstract}
Apstrakt
Cilj ovog istraživanja je validacija srpske adaptacije Collett-Lester skale straha od smrti (CLFODS-R). Na uzorku od 263 ispitanika (66\% ženskog pola), starosti od 18 do 65 godina, pored CLFODS-R, primenjeni su Velikih pet plus dva-70 i Inventar za procenu pozitivnog i negativnog afekta (PANAS). Rezultati potvrđuju originalno predloženu četvorofaktorsku stukturu skale u okviru koje se razlikuju strah od sopstvene smrti, strah od sopstvenog umiranja, strah od smrti druge osobe i strah od umiranja druge osobe. Sve četiri dimenzije značajno pozitivno koreliraju sa negativnim afektom i neuroticizmom, dok korelacije sa pozitivnim afektom i ekstraverzijom nisu značajne, što ide u prilog validnosti skale. Pored toga, žene ostvaruju više skorove na svim dimenzijama, a stariji ispitanici i oni sa iskustvom smrti bliske osobe imaju manji strah od smrti u nekim njenim aspektima. Rezultati upućuju na to da je srpska adaptacija CLFODS-R validna i pouzdana mera, te da može naći primenu u daljim ispitivanjima straha od smrti.
\end{abstract}

Ključne reči: strah od sopstvene smrti, strah od smrti druge osobe, Collett-Lester skala straha od smrti, faktorska analiza, validnost

\section{Uvod}

Strah od smrti predstavlja nelagodno osećanje koje ljudi imaju pri razmišljanju o smrti ili umiranju (Dadfar, Abdel-Khalek, Lester, \& Atef Vahid, 2017). Strah od smrti je nalik ostalim ne-neurotskim strahovima koje ljudi doživljavaju svakodnevno (Mooney \& O’Gorman, 2001). Iako je strah od smrti prisutan u opštoj populaciji generalno, najviše primenjenih istraživanja u ovoj oblasti je bilo na osobama koje su blizu smrti, kao što su osobe koje boluju od neizlečivih bolesti (terminalni pacijenti)

\footnotetext{
${ }^{1}$ bojana.dinic@ff.uns.ac.rs

${ }^{2}$ Zahvalnica. Autori se zahvaljuju kolegama Luki Todoroviću i Mariji Bulat na pomoći u prevodu skale i realizaciji istraživanja.

Deo rezultata je prikazan u: Todorović, L., Bulat, M., Petrović, K. i Dinić, B. (2018). Validacija srpske adaptacije skale Straha od smrti. Poster prezentovan na naučno-stručnom skupu Peti sarajevski dani psihologije, Sarajevo, Bosna i Hercegovina. Rad je nastao u okviru projekta Ministarstva prosvete, nauke i tehnološkog razvoja (ON179006).
} 
ili stari. Pokazano je da anksioznost u vezi sa smrću ima negativan efekat na kvalitet života i razvoj disfunkcionalnih stavova kod obolelih od raka i osoba koje se o njima staraju (Lau et al., 2018). Ipak, Carmel i Mutran (1997) pokazali su da je dobijena pozitivna korelacija između straha od smrti i traženja medicinskih intervencija usmerenih na održavanje života kod starih ljudi, te u tom smislu on može imati motivacioni karakter.

Strah od smrti je operacionalizovan na različite načine, te ga neki autori tretiraju kao jednodimenzionalni, a drugi kao višedimenzionalni konstrukt, pri čemu ne postoji slaganje u vezi sa sadržajem i strukturom dimenzija (npr. Neimeyer, Moser, \& Wittkowski, 2003). Tako, među prvim skalama koje operacionalizuju ovaj konsturkt, nastala je 15-ajtemska jednodimenzionalna Skala anksioznosti u vezi sa smrću (Death Anxiety Scale - DAS: Templer, 1970). Ubrzo nakon objavljivanja skale i sam autor predlaže dvofaktorsku teoriju anksioznosti u vezi sa smrću po kojoj anksioznost može biti determinisana generalnim psihološkim zdravljem i specifičnim iskustvima u vezi sa smrću (Templer, 1976). Neimeyer (1994) zapaža da je nemoguće utvrditi da li dve osobe koje imaju isti skor na skali imaju radikalno drugačije vidove straha od smrti, te većina autora predlaže da se ovaj konstrukt sagleda kao multidimenzionalni. Višedimenzionalnost ovog konstrukta delimično podupiru i nalazi koji sugerišu da jednodimenzionalne skale pri ponovnoj faktorskoj analizi pokazuju veći broj faktora (npr. Sharif Nia et al., 2019; Levin, 1990).

Do sada je razvijeno 10-ak skala koje se odnose na neki aspekt smrti, poput straha od smrti, anksioznosti ili depresivnosti u vezi sa smrću i slično (jedan uži pregled skala u vezi s anksioznosti u vezi sa smrću može se naći u Cai et al., 2017). Od višedimenzionalnih mera, među najkorišćenijim je npr. Multidimenzionalna skala straha od smrti (Multidimensional Fear of Death Scale - MFODS: Hoelter, 1979) koja se sastoji od 42 ajtema raspoređena u osam dimenzija: strah od procesa umiranja, strah od mrtvih, strah od sopstvenog uništenja, strah za bližnje, strah od nepoznatog, strah od postojanja svesti nakon smrti, strah za telo nakon smrti i strah od prerane smrti. Skala je validirana na većem uzorku studenata, a pouzdanosti dimenzija, izražene preko Kronbahovog alfa koeficijenta, se kreću u rasponu od .65 do .82. Do sada je skala adaptirana na španski jezik, pri čemu je osmofaktorska struktura potvrđena, ali su preporučena i dva faktora višeg reda - strahovi pre smrti i strahovi posle smrti, čime je bolje i određen fokus ove skale (Borges Hernández \& De Miguel Negredo, 2020).

Pored MFODS, još jedna multidimenzionalna skala je revidirana DAS skala kojoj su dodata još 36 ajtema, tako da ukupno sadrži 51 ajtem (Death Anxiety Scale Extended - DASE: Templer et al., 2006). U finalnoj formi uključuje 10 aspekata anksioznosti povodom smrti: eksterne uzroke smrti, pomisao na smrt, mučan bol, strah od operacije, predstave o smrti, blizina smrti, prisustvo smrti, negiranje anksioznosti zbog smrti, snovi o smrti i misli o smrti. Međutim, 10-faktorska struktura nije potvrđena u kasnijim primenama na drugim jezicima (npr. na persijskom, više u Sharif Nia et al., 2017). Takođe, postoji i određeni broj novijih multidimenzionalnih mera straha od smrti, npr. Inventar anksioznosti u vezi sa smrću (Death Anxiety Inventory - DAI: Tomás-Sábado \& Gómez-Benito, 2005) koji je originalno nastao 
na španskom jeziku. Ovaj inventar je nastao na osnovu Templerove teorije kojoj je pridodata i podela na eksterne i interne generatore straha od smrti (Lester \& Templer, 1993). Struktura ovog inventara ukazuje na to da se može detektovati jedan faktor koji se odnosi na eksterne generatore (npr. groblje) i četiri faktora koji se odnose na interne generatore anksioznosti u vezi sa smrću (npr. uverenja i razmišljanja o smrti ili životu nakon smrti), te se može primetiti da je veća raznovrsnost internih generatora. Međutim, istraživanja pokazuju da su ajtemi koji se odnose na interne generatore (npr. uverenja) više povezani sa anksioznošću u vezi sa smrću nego oni koji se odnose na eksterne generatore (npr. učestalost obavljanja religijskih rituala, više u Templer et al., 2006), tako da smo mišljenja da internim generatorima treba dati primat u definisanju straha od smrti. Takođe, od novih skala predložena je i Arapska skala anksioznosti u vezi sa smrću (Arabic Scale of Death Anxiety - ASDA: Abdel-Khalek, 2004) ali je konstruisana za drugačiji kulturni kontekst od našeg.

Još jedna višedimenzionalna skala koja se često koristi je i Collett-Lester skala straha od smrti koja je prvi put spomenuta 1969. (Collett-Lester Fear of Death Scale - CLFODS: Collett \& Lester, 1969), a objavljena je 1990., zajedno sa svojom prvom revizijom (Lester, 1990). Prva revidirana verzija ove skale napravljena je radi ujednačavanja broja ajtema u subskalama, a sastoji se od četiri dimenzije sa po 8 ajtema: 1. strah od sopstvene smrti, koji se odnosi na strah od prestanka sopstvenog postojanja, uz nemogućnost daljeg doživljavanja stvari; 2. strah od sopstvenog umiranja, koji se odnosi na strah od nedostatka kontrole nad procesom umiranja, fizičkog i intelektualnog propadanja tokom umiranja, kao i bol koji ovaj proces donosi; 3. strah od tuđe smrti, koji se pretežno odnosi na strah od gubitka bliske osobe i strah od usamljenosti, dok se deo ajtema odnosi na žaljenje i osećanje krivice zbog nedovoljno dobrog tretmana osobe pre smrti ili zbog olakšanja nakon njene smrti; 4. strah od tuđeg umiranja, koji sadrži ajteme koji se odnose na strah od uključenosti u proces tuđeg umiranja, te od posmatranja druge osobe u patnji, fizičkom i mentalnom propadanju i neznanje kako joj pomoći. Split-half pouzdanosti dimenzija u originalnom istraživanju su se kretale redom .91, .89, .72 i .87. Pored toga, ispitivana je i test-retest pouzdanost, ali je period između dva testiranja bio samo dva dana (pouzdanosti su redom iznosile $.85, .79, .86, .83$ ).

Skala je drugi put revidirana 2003. godine na uzorku studenta (CLFODS-R: Lester \& Abdel-Khalek, 2003), a revizija se sastoji u skraćivanju skale na po 7 ajtema po subskali čime je izbačen i jedini negativno kodiran ajtem. Revizija je urađena upravo zbog loših metrijskih karakteristika spomenutog inverzno kodiranog ajtema. Pouzdanost subskala ove verzije je sledeća: strah od sopstvene smrti $\alpha=.91$, strah od sopstvenog umiranja $\alpha=.92$, strah od smrti druge osobe $\alpha=.88$ i strah od umiranja druge osobe $\alpha=.92$. Pokazano je da su subskale iz CLFODS-R u značajnoj i umerenoj do visokoj korelaciji sa pojedinim dimenzijama iz MFOD skale (Mooney \& O’Gorman, 2001), čime je njena konstrukt validnost potvrđena.

Interesovanje za CLFODS-R skalu među istraživačima je aktivno. Skala je nedavno adaptirana i validirana na drugim jezicima, npr. na španskom (Tomás-Sábado, Limonero, \& Abdel-Khalek, 2007), persijskom (Naderi \& Esmaili, 2009) i češkom jeziku (Bužgová \& Janíková, 2019) u kojima je potvrđena četvorofaktorska struktura 
skale i njena pouzdanost. Cilj ovog rada je da se ispitataju psihometrijske karakteristike skale CLFODS-R na srpskom jeziku. Postoji nekoliko prednosti ove skale u odnosu na ostale. Najpre, u odnosu na MFODS i DASE, CLFODS-R je kraća i pokazuje bolje metrijske karakteristike i stabilniju strukturu. Potom, sistematičnost ove skale je još jedan razlog za njen odabir, odnosno jasno odvajanje pojma smrti od pojma umiranja i odvajanje percepcije svoje smrti i smrti bližnjih. Neki nalazi ukazuju na to da čak i osobe sa relativno niskom anksioznošću povodom svoje smrti mogu da osećaju visok nivo anksioznosti pri pomisli na smrt ili umiranje sebi bliskih osoba (Bath, 2010). Dok i drugi instrumenti koje smo naveli imaju supskale koje se odnose na razlikovanje ovih aspekata, oni nisu stavljeni u prvi plan, a neke od skala imaju i ajteme ili supskale koje se mogu odnositi i na druge konstrukte koji nisu u direktnoj vezi sa smrću i umiranjem (npr. supskala straha od nepoznatog u MFODS-u). Na kraju, validnost CLFODS-R je više proveravana kroskulturno, te bi adaptacija ove skale na srpskom mogla doprineti boljem uvidu u kroskulturne razlike.

Prethodna istraživanja u vezi s validacijom skala straha od smrti ispitivala su povezanost straha od smrti sa demografskim i drugim karaktristikama, poput bazičnih osobina ličnosti. U većini istraživanja je dobijen nalaz da se stariji ispitanici manje plaše smrti od mlađih (Cicirelli, 1999; Patton \& Freitag, 1977; Smith, Nehemkis, \& Charter, 1984; Tomer, 1994), mada postoje pojedine studije u kojima nisu dobijene starosne razlike (Conte, Weiner, \& Plutchik, 1982). Takođe, iskustvo skore smrti osobe koju poznajemo je negativno povezano sa strahom od smrti (npr. Patton \& Freitag, 1977; Yang \& Chen, 2009). U vezi s polom, nalazi prethodnih istraživanja nisu dosledni, ali u većini radova je dobijeno da se ženske osobe više plaše smrti (npr. Cicirelli, 1999; Naderi \& Esmaili, 2009; Patton \& Freitag, 1977), dok određeni broj radova ne nalazi polne razlike (Conte et al., 1982; Loo, 1984), pri čemu moramo napomenuti da su to stariji radovi koji su bazirani na manjim uzorcima. Od osobina ličnosti, strah od smrti je pozitivno povezan sa generalnom anksioznošću (Patton \& Freitag, 1977; TomásSábado el al., 2007) i neuroticizmom (Frazier \& Foss-Goodman, 1988; Loo, 1984), dok ne ostvaruje korelaciju sa ekstraverzijom (Galton, 2019; Loo, 1984; Oral, 2017).

Cilj ovog istraživanja je validacija srpske adaptacije revidirane verzije Collett-Lester skale straha od smrti. Konstrukt validnost je ispitivana na dva načina. Najpre je proveravana faktorska struktura skale, pri čemu očekujemo da će originalna četvorofaktorska struktura pokazati dobre indikatore fita. Potom, ispitivana je konvergentna i diskriminativna validnost skale preko korelacija sa bazičnim osobinama ličnosti i dominantnim afektom. U prethodnim istraživanjima se relacije sa afektom nisu ispitivale, ali s obzirom na to da je neuroticizam povezan s negativnim afektom, a ekstraverzija sa pozitivnim afektom, te da negativan i pozitivan afekat ne koreliraju značajno (Watson, Clark, \& Tellegen, 1988), postavili smo sledeća očekivanja. Očekuje se da će skorovi na CLFODS-R skali pozitivno korelirati sa neuroticizmom i negativnim afektom, pre svega sa subskalom straha iz domena negativnog afekta (konvergentna validnost), dok se ne očekuje značajna korelacija sa ekstraverzijom i pozitivnim afektom (diskriminativna validnost). Drugim rečima, diskriminativna validnost će biti potvrđena ukoliko CLFODS-R pokazuje jače veze sa neuroticizmom i negativnim afektom, u odnosu na jačinu veza sa ekstraverzijom i pozitivnim afektom 
(za koje se može očekivati da nisu značajne ili da su upadljivo niske). Na kraju, očekuje se i negativna korelacija sa starošću i skorijom smrti bliske osobe, kao i polne razlike, u smeru veće izraženosti straha od smrti kod žena.

\section{Metod}

\section{Uzorak}

Uzorak je činilo 263 ispitanika ( $66 \%$ osoba ženskog pola), starosti od 18 do 65 godina $(A S=26.37, S D=9.02, M d=22)$. Većina ispitanika su bili studenti $(60 \%)$, dok je $28.13 \%$ ispitanika imalo završenu višu školu, fakultet ili više od toga. Od ukupnog uzorka, 37.64\% ispitanika je izjavilo da je u skorijem periodu doživelo smrt bliske osobe. Uzorak je prikupljen onlajn, principom snežne grudve. Nije bilo nedostajućih podataka.

\section{Instrumenti}

Collett-Lester skala straha od smrti - revidirana verzija (Collett-Lester Fear of Death Scale-Revised - CLFODS-R; Lester \& Abdel-Khalek, 2003). Skala se sastoji od 28 ajtema raspoređenih u četiri supskale (svaka sadrži po 7 ajtema): Strah od sopstvene smrti, Strah od sopstvenog umiranja, Strah od smrti druge osobe i Strah od umiranja druge osobe. Uputstvo za zadavanje je sledeće: "Koliko Vas uznemiravaju ili čine zabrinutim sledeći aspekti smrti i umiranja? Pročitajte svaku tvrdnju i odgovorite što je moguće brže. Ne razmišljajte previše o odgovoru. Želimo Vaš prvi utisak o tome kako sada razmišljate. Zaokružite broj koji najbolje predstavlja kako se osećate, pri čemu brojevi mogu da se kreću od $1=$ uopšte me ne uznemirava ili brine do $5=$ veoma me uznemirava ili brine. Skala je adaptirana na srpski jezik putem povratnog prevoda, a adaptaciju su izvršili članovi istraživačkog tima studenata s Odseka za psihologiju Filozofskog fakulteta u Novom Sadu pod mentorstvom.

Velikih pet plus dva-70 (VP+2-70; Čolović, Smederevac i Mitrović, 2014). Ovo je kraća forma inventara Velikih pet plus dva koji meri sedam dimenzija ličnosti ekstrahovanih na osnovu leksičke studije na srpskom jeziku (svaka dimenzija sadrži po 10 ajtema): Ekstraverziju ( $\alpha=.89)$, Neuroticizam $(\alpha=.88)$, Agresivnost $(\alpha=.86)$, Otvorenost ( $\alpha=.80)$, Savesnost $(\alpha=.92)$, Pozitivnu valencu $(\alpha=.89)$ i Negativnu valencu $(\alpha=.83)$. Odgovori se daju na petostepenoj skali Likertovog tipa (od $1=$ uopšte se ne slažem do $5=$ u potpunosti se slažem).

Inventar za procenu pozitivnog i negativnog afekta (PANAS-X; Watson et al., 1988, za srpsku adaptaciju videti Mihić, Novović, Čolović, \& Smederevac, 2014). PANAS-X je kraća verzija PANAS inventara koja sadrži 20 ajtema tj. prideva kojima se opisuje Pozitivan afekat $(\alpha=.88, n=10)$ i Negativan afekat $(\alpha=.90$, $n=10)$. Pozitivan afekat sadrži tri facete: Samopouzdanje, Radost i Budnost, a Negativan afekat sadrži sledeće facete: Strah, Samoprezir i Hostilnost. Ispitanici su na petostepenoj Likertovoj skali (od 1 = veoma malo ili nimalo do 5 = izuzetno, jako) procenjivali kako se uobičajeno osećaju. 


\section{Obrada podataka}

Struktura skale je testirana preko konfirmatorne faktorske analize. Budući da podaci odstupaju značajno od multivarijatne normalnosti (Mardia $=908.74, p<.001$, multivarijatni kurtozis iznosi 13.6) primenjen je robusni metod (eng. diagonally weighted least squares - DWLS). Fit modela je određen preko nekoliko indikatora: prihvatljivim fitom se smatra Bentlerov komprativni indeks fita (CFI) i Nenormirani indeks fita (NNFI) $\geq .95$, kvadratni koren prosečne kvadrirane greške aproksimacije (RMSEA) $\leq .08$ i standardizovani kvadratni koren prosečnog kvadrata reziduala $(\mathrm{SRMR}) \leq .10$, a dobrim CFI i NNFI $\geq .97$, RMSEA i SRMR $\leq .05$ (SchermellehEngel, Moosbrugger, \& Müller, 2003). Za poređenje modela je koriščen $\Delta \chi^{2}$ za broj stepeni koji se odnosi na razliku u broju stepeni slobode dva modela. Analiza je sprovedena u paketu "lavaan" (Rosseel, 2012) za R okruženje (R Core Team, 2017). U cilju provere konvergentne i diskriminativne validnosti, kao i relacije sa starošču, izračunate su Pirsonove korelacije sa skalama CLFODS-R-a. Kako bi se kontrolisala greška tipa 1 , primenjena je Bonferroni korekcija $p$-nivoa. Polne razlike i razlike između onih koji su imali iskustvo smrti bliske osobe i onih koji to nisu u skalama CLFODS-R testirane su $t$-testom za nezavisne uzorke. Kao mera veličine efekta korišćeni su Koenov $d$ čije vrednosti 0.20 upućuju na malu, 0.50 na srednju i 0.80 na veliku veličinu efekta, i parcijalni eta kvadrat $\left(\eta_{\mathrm{p}}{ }^{2}\right)$ čije vrednosti .01 ukazuju na malu, 0.06 na srednju i 0.14 na veliku veličinu efekta (Cohen, 1988).

\section{Rezultati}

Rezultati konfirmatorne faktorske analize ukazuju na to da je originalni četvorofaktorski model bolji od jednofaktorskog $\left(\Delta \chi^{2}(6)=395.18, p<.001\right.$, za fit modela videti Tabelu 1), te da su indeksi fita četvorofaktorskog modela dobri i svi parametri na pripadajućem faktoru visoki (Tabela 2). Najviši indeksi modifikacije modela upućuju na to da bi se ajtem 28 mogao prelocirati u okviru prvog i drugog faktora. Ukoliko se dopusti da ovaj ajtem bude obuhvaćen u tri faktora, svakako da su indeksi fita značajno bolji $\left(\Delta \chi^{2}(2)=82.86, p<.001\right)$, ali je opterećenje ovog ajtema upadljivo niže na faktiorima $(.23, .36$ i .22). S obzirom na to, zadržaćemo originalnu strukturu, a na ovaj rezultat osvrnuti u diskusiji.

Tabela 1

Indikatori fita predloženih modela srpske adaptacije revidirane Collett-Lester skale straha od smrti

\begin{tabular}{lcccll}
\hline Model & DWLS $\chi^{2}(d f)$ & CFI & NNFI & $\begin{array}{l}\text { RMSEA } \\
(90 \% \text { CI })\end{array}$ & SRMR \\
\hline jednofaktorski & $983.21(350)$ & .94 & .94 & $.08(.08-.09)$ & .10 \\
četvorofaktorski & $588.03(344)$ & .98 & .97 & $.05(.05-.06)$ & .08 \\
\hline
\end{tabular}


Tabela 2

Konfirmatorna faktorska analiza: opterećenja na faktorima srpske adaptacije revidirane Collett-Lester skale straha od smrti

\begin{tabular}{|c|c|c|c|c|c|}
\hline & \multirow[b]{2}{*}{ Ajtem } & \multicolumn{4}{|c|}{ Faktor } \\
\hline & & 1 & 2 & 3 & 4 \\
\hline 1. & Totalno nepostojanje nakon smrti & .63 & & & \\
\hline 2. & Kratak život & .73 & & & \\
\hline 3. & Sve što se propušta nakon smrti & 69 & & & \\
\hline 4. & Umreti mlad & .63 & & & \\
\hline 5. & Kakav je osećaj biti mrtav & .61 & & & \\
\hline 6. & Da se nikada više neće misliti ili doživeti išta & .69 & & & \\
\hline 7. & Raspadanje Vašeg tela nakon smrti & .56 & & & \\
\hline 8. & Fizičko propadanje tokom umiranja & & .49 & & \\
\hline 9. & Bol koji umiranje donosi & & .63 & & \\
\hline 10. & Intelektualno propadanje kao posledica starenja & & .54 & & \\
\hline 11. & Ograničenost Vaših sposobnosti na samrti & & 60 & & \\
\hline 12. & Nesigurnost u to koliko ćete se hrabro nositi sa procesom umiranja & & .79 & & \\
\hline 13. & Vaš nedostatak kontrole nad procesom umiranja & & .78 & & \\
\hline 14. & Mogućnost da umrete u bolnici, daleko od prijatelja i porodice & & .71 & & \\
\hline 15. & Gubitak nekoga ko Vam je blizak & & & .66 & \\
\hline 16. & Kada se mora videti mrtvo telo te osobe & & & .62 & \\
\hline 17. & Nemogućnost da ikada više pričate sa tom osobom & & & 67 & \\
\hline 18. & Žaljenje što niste bili ljubazniji prema toj osobi dok je bio/la živ/a & & & .61 & \\
\hline 19. & Ostariti sam, bez te osobe pored sebe & & & .73 & \\
\hline 20. & Krivica što osećate olakšanje zbog smrti te osobe & & & .55 & \\
\hline 21. & Osećanje usamljenosti bez te osobe & & & .68 & \\
\hline 22. & Da morate biti sa nekim ko umire & & & & 60 \\
\hline 23. & Želja te osobe da priča sa Vama o smrti & & & & .55 \\
\hline 24. & Gledati tu osobu kako pati od bola & & & & .59 \\
\hline 25. & Gledati fizičko propadanje tela te osobe & & & & 66 \\
\hline 26. & Neznanje o tome kako se nositi sa bolom usled gubitka te osobe & & & & .73 \\
\hline 27. & Gledati kako propadaju mentalne sposobnosti te osobe & & & & .53 \\
\hline 28. & Podsećanje na to da ćete i Vi proći kroz isto iskustvo jednog dana & & & & .74 \\
\hline
\end{tabular}

Napomena. 1 = Strah od sopstvene smrti, 2 = Strah od sopstvenog umiranja, $3=$ Strah od smrti druge osobe, $4=$ Strah od umiranja druge osobe.

Skjunes (od -.54 to .31) i kurtozis (od -.15 do -.76) skorova na skalama su bili u granicama preporučenih za normalnu distribuciju ( \pm 2 , videti Gravetter \& Wallnau, 2014). Korelacije između četiri dimenzije su umerene do visoke, i kreću se od .48 (između straha od sopstvenog umiranja i od smrti druge osobe) do .74 (između straha od smrti i od umiranja druge osobe). Prosečna inter-ajtemska korelacija ajtema u okviru dimenzije iznosi .42 ili .43 , što je u preporučenom rangu kada su u pitanju uži konstrukti poput faceta (više u Dinić, 2019). Drugim rečima, čini se da nema redundantnih ajtema u okviru dimenzija (na ovo nam ukazuje i podatak da nema diskriminativnosti koje su iznad .80, tačnije, najviša diskriminativnost ajtema je .70, više u Dinić, 2019) 
Korelacije svih aspekata straha od smrti sa neuroticizmom su značajne i pozitivne, dok korelacije sa ekstraverzijom nisu značajne. Nisu značajne ni korelacije sa ostalim osobinama ličnosti, osim negativne niske korelacije između pozitivne valence i straha od tuđe smrti, međutim nakon uvođenja Bonferroni korekcije ova korelacija nije ostvarila značajnost.

Korelacije sa dimenzijama afekta pokazuju da sve četiri dimenzije straha od smrti ostvaruju značajnu i pozitivnu korelaciju sa negativnim afektom, dok korelacije sa pozitivnim afektom nisu značajne (Tabela 3). Od supskala negativnog afekta, sve četiri dimenzije straha od smrti ostvaruju dosledno pozitivne i značajne korelacije sa afektom straha, dok strah od sopstvenog umiranja i strah od tuđe smrti ostvaruju značajne pozitivne korelacije sa samoprezirom. Iako postoje značajne pozitivne korelacije ostalih aspekata straha od smrti sa samoprezirom i svih aspekata straha od smrti sa hostilnošću, ove korelacije nisu značajne nakon uvođenja Bonferroni korekcije. Na osnovu rezultata može se pretpostaviti da je negativan afektivitet ključni korelat straha od smrti.

Tabela 3

Korelacije između dimenzija srpske adaptacije revidirane Collett-Lesterskale straha od smrti, bazičnih osobina ličnost, mera afekta i starosti

\begin{tabular}{|c|c|c|c|c|c|c|c|c|c|c|c|c|c|c|c|}
\hline & \multirow[b]{2}{*}{$A S(S D)$} & \multirow[b]{2}{*}{$\alpha$} & \multicolumn{7}{|c|}{ Velikih pet plus dva } & \multicolumn{5}{|c|}{ PANAS } & \multirow{2}{*}{ Starost } \\
\hline & & & $\mathrm{E}$ & $\mathrm{N}$ & A & $\mathrm{S}$ & $\mathrm{O}$ & PV & NV & PA & NA & Strah & Samopr. & Host. & \\
\hline SS & $18.03(7.10)$ & .83 & .09 & $.23^{\text {th }}$ & .10 & .03 & -.02 & .03 & .08 & .08 & $.28^{* *}$ & $.32 \% *$ & $.19 * *$ & $.13 *$ & $-.21^{k+k}$ \\
\hline SU & $22.09(6.90)$ & .84 & -.06 & $.29^{n k}$ & .03 & .00 & -.01 & .02 & .08 & -.01 & $.29^{* *}$ & $.32 * *$ & $.21 * *$ & $.14 *$ & -.04 \\
\hline TS & $25.27(6.10)$ & .83 & -.03 & $.27^{\text {kn }}$ & .09 & -.09 & -.05 & $-.12^{*}$ & -.02 & -.04 & $.26^{* *}$ & $.28 * *$ & $.22 * *$ & $.12 *$ & $-.13^{*}$ \\
\hline $\mathrm{TU}$ & $24.29(5.92)$ & .83 & -.10 & $.30^{\text {kn }}$ & .06 & -.06 & -.07 & -.09 & .05 & -.06 & $.25^{* \star}$ & $.28 * *$ & $.18 * *$ & $.15^{*}$ & -.10 \\
\hline
\end{tabular}

Napomena. SS = strah od sopstvene smrti, SU = strah od sopstvenog umiranja, TS = strah od tuđe smrti, TU = strah od tuđeg umiranja; $\mathrm{E}=$ ekstraverzija, $\mathrm{N}=$ neuroticizam, $\mathrm{P}=$ prijatnost, $\mathrm{S}=$ savesnost, $\mathrm{O}=$ otvorenost, $\mathrm{PV}=$ pozitivna valenca, $\mathrm{NV}=$ negativna valenca, $\mathrm{PA}=$ pozitivan afekat, NA = negativan afekat, Host. = Hostilnost, Samopr. = Samoprezir; ${ }^{*} p<.05,{ }^{*} p<.01$. Boldovane korelacije su značajne nakon primene Bonferroni korekcije ( $p$ $=.0009615)$.

U vezi s relacijama sa demografskim i drugim karakteristikama, dobijena je značajna negativna korelacija starosti sa strahom od sopstvene i tuđe smrti, dok nema značajnih povezanosti sa strahom od sopstvenog i tuđeg umiranja (Tabela 3). Polne razlike ${ }^{3}$ su dobijene na svim supskalama CLFODS-R, u smeru u kojem žene pokazuju više straha od smrti u odnosu na muškarce (Tabela 4). Sve polne razlike su

\footnotetext{
${ }^{3}$ Preliminarno smo proverili invarijantost $\mathrm{u}$ odnosu na pol preko multigrupne konfirmatorne faktorske analize i rezultati pokazuju da je ona ostvarena budući da nema značajnih razlika između testiranih modela, tj. $\triangle$ CFI je manja od .01 i $\triangle$ RMSEA manja od -.015 (Cheung \& Rensvold, 2002): konfiguralni nivo: $\mathrm{CFI}=.995, \mathrm{TLI}=.994, \mathrm{RMSEA}=.024, \mathrm{SRMR}=.086$; metrični nivo: $\mathrm{CFI}=.990, \mathrm{TLI}=.989$, $\mathrm{RMSEA}=.033, \mathrm{SRMR}=.086$; skalarni nivo: $\mathrm{CFI}=.988, \mathrm{TLI}=.987, \mathrm{RMSEA}=.036, \mathrm{SRMR}=.091$. Ipak, kako je uzorak mali za ove analize, rezultati će se uzeti s rezervom.
} 
srednje veličine efekta. S obzirom na moguće polne razlike u neuroticizmu (Furnham \& Buchanan, 2005), koje mogu uzorkovati razlike i u strahu od smrti, polne razlike su testirane uz statističku kontrolu neuroticizma. Rezultati potvrđuju postojanje značajnih polnih razlika u svim dimenzijama $(F(1,260)$ se kreće u rasponu od 5.50 do 10.13), osim u slučaju straha od sopstvenog umiranja $(F(1,260)=3.53, p=$ .061). Veličina efekta ukazuje na to da su sve polne razlike uz kontrolu neuroticizma srednje veličine, kao i u slučaju kad neuroticizam nije kontrolisan. Dakle, polne razlike nisu pod uticajem razlika u neuroticizmu.

Tabela 4

Polne razlike u rezultatima na Collett-Lesterskali straha od smrti

\begin{tabular}{|c|c|c|c|c|c|}
\hline & Muškarci & Žene & \multirow{2}{*}{$t(261)$} & \multirow{2}{*}{$d$} & \multirow{2}{*}{$\eta_{\mathrm{p}}^{2}$} \\
\hline & $A S(S D)$ & $A S(S D)$ & & & \\
\hline Strah od sopstvene smrti & $16.1(6.32)$ & $19.02(7.29)$ & $-3.21 * *$ & 0.40 & .030 \\
\hline Strah od sopstvenog umiranja & $20.71(7.13)$ & $22.8(6.69)$ & $-2.34 *$ & 0.29 & .013 \\
\hline Strah od tuđe smrti & $23.43(6.55)$ & $26.21(5.64)$ & $-3.58 * *$ & 0.44 & .037 \\
\hline Strah od tuđeg umiranja & $22.88(6.10)$ & $25.02(5.71)$ & $-2.81 * *$ & 0.35 & .021 \\
\hline
\end{tabular}

Napomena. $d=$ Koenov $d$ kao mera veličine efekta za polne razlike, $\eta_{\mathrm{p}}{ }^{2}=$ parcijalni eta kvadrat kao mera veličine efekta za polne razlike uz kontrolu neuroticizma; ${ }^{*} p<.05,{ }^{*} p<.01$.

Razlike između onih koji su imali iskustvo smrti bliske osobe $\mathrm{i}$ onih koji to nisu je značajna samo u slučaju supskala straha od sopstvene smrti i straha od tuđeg umiranja, u smeru u kojem veći strah pokazuju oni koji nemaju iskustvo smrti bliske osobe (Tabela 5). Obe razlike su srednje veličine efekta.

Tabela 5

Razlike u odnosu na iskustvo smrti bliske osobe u rezultatima na Collett-Lester skali straha od smrti

\begin{tabular}{|c|c|c|c|c|}
\hline & $\begin{array}{c}\text { Ima iskustvo } \\
\text { smrti } \\
\text { bliske osobe }\end{array}$ & $\begin{array}{c}\text { Nema iskustvo smrti } \\
\text { bliske osobe }\end{array}$ & $t(261)$ & $d$ \\
\hline & $A S(S D)$ & $A S(S D)$ & & \\
\hline Strah od smrti & $16.53(6.79)$ & $18.94(7.15)$ & $-2.70 * *$ & 0.33 \\
\hline Strah od sopstvenog umiranja & $21.74(6.97)$ & $22.30(6.87)$ & -0.65 & 0.08 \\
\hline Strah od tuđe smrti & $24.87(6.50)$ & $25.51(5.85)$ & -0.83 & 0.10 \\
\hline Strah od tuđeg umiranja & $23.37(6.18)$ & $24.85(5.71)$ & $-1.97 *$ & 0.24 \\
\hline
\end{tabular}

Napomena. $d=$ Koenov $d$ kao mera veličine efekta; $* p<.05, * * p<.01$.

\section{Diskusija}

Cilj ovog istraživanja bio je psihometrijska evaluacija srpske adaptacije revidirane Collett-Lester skale straha od smrti. Rezultati konfirmatorne faktorske analize ukazuju na to da originalno četvorofaktorsko rešenje pokazuje dobre 
indikatore fita modela, te bolje od jednofaktorskog modela. Ovaj rezultat upućuje na to da se mogu razlikovati faktori koji se odnose na strah od sopstvene smrti, sopstvenog umiranja, tuđe smrti i tuđeg umiranja. Prethodna istraživanja pokazuju da bez obzira na stepen prisustva straha od sopstvene smrti, većina osoba ima strah od smrti ili umiranja druge osobe, te da je opravdano praviti razliku između straha od sopstvene smrti od straha od smrti druge osobe (Bath, 2010). Pored toga, iako postoji umerena do visoka povezanost između straha od umiranja i straha od smrti, ova dva aspekta straha se ipak mogu razlikovati. Da ljudi diferenciraju proces umiranja od stanja smrti takođe pokazuju i korelacije sa starošću, pri čemu se strah od smrti smanjuje sa starošću, ali strah od umiranja ne ostvaruje značajnu korelaciju sa starošću.

Međutim, uvidom u indekse modifikacije je zaključeno da jedan ajtem koji originalno pripada faktoru straha od umiranja druge osobe (ajtem 28, "Podsećanje na to da ćete i Vi proći kroz isto iskustvo jednog dana"), može da se prelocira u faktore koji se odnose na strah od sopstvene smrti i umiranja. Ovo je jedini ajtem u okviru faktora straha od umiranja druge osobe koji obuhvata i lični doživljaj straha od umiranja, tako da se sadržinski uklapa u strah od sopstvenog umiranja. Međutim, kada se dozvoli korelacija ovog ajtema s faktorima koji se odnose na strah od sopstvene smrti i umiranja, doprinos ovog ajtema je upadljvo nizak. S obzirom na to, možemo zaključiti da je originalna struktura upitnika potvrđena, ali da ima prostora za modifikaciju ajtema na način da budu uže vezani za aspekte straha od smrti.

Konvergentna validnost skale je potvrđena s obzirom na to da sve četiri subskale CLFODS-R ostvaruju značajnu pozitivnu povezanost sa negativnim afekatom i neuroticizmom, što je u skladu s ranijim istraživanjima (npr. Frazier \& Foss-Goodman, 1988; Tomás-Sábado et al., 2007). Diskriminativna validnost je takođe potvrđena s obzirom na to da nijedna od četiri dimenzije revidirane CollettLester skale straha od smrti ne ostvaruje značajne korelacije sa pozitivnim afektom i ekstraverzijom. Drugim rečima, prisustvo negativnog afekta i negativnih emocija poput tuge, zabrinutosti i slično je ključna karakterstika straha od smrti. Korelacije sa afektom i osobinama ličnosti su generalno niske, što upućuje na zaključak da se strah od smrti ne može svesti na negativan afekat, ni na generalni strah kao aspekt negativnog afekta, ili na neku osobinu ličnosti, te da su u pitanju distinktivni konstrukti.

Takođe smo očekivali i da bi skorija smrt bliske osobe bila povezana sa nižim strahom od smrti (npr. Normand \& Mishara, 1992). Ova hipoteza je donekle potvrđena, s obzirom na to da je dobijeno da osobe koje imaju ovakvo iskustvo imaju manji strah od sopstvene smrti i od tuđeg umiranja, pri čemu je veći efekat dobijen u slučaju straha od sopstvene smrti. Mogući razlog za ovakav nalaz mogao bi biti demistifikacija smrti, pri čemu bi oni koji su iskusili smrt bliske osobe bili "pripremljeniji" na činjenicu da će i sami umreti, te imaju bolje razumevanje smrti i moguće znanje o načinima kako mogu da se nose s tim, što posledično smanjuje strah.

Neznačajne razlike u strahu od smrti druge osobe možda pre upućuju na nepostojanje razlika u emotivnoj komponenti, kao što je strah od bola i patnje kroz 
koju bismo prolazili, nego u kognitivnoj kao što je poznavanje procesa umiranja i smrti. Naime, prethodna istraživanja upućuju na to da je strah od smrti bliske osobe izraženiji i svojstven svima i da se javlja nezavisno od straha od sopstvene smrti (Bath, 2010). Strah od smrti bliske osobe bi se mogao objasniti strahom od bola, kako nas ideja o umiranju nama bliskih više podseća na patnju koju bismo mi sami prolazili nego na smrt kao pojam.

U kontekstu polnih razlika, dobijen je nalaz da žene ostvaruju značajno više skorove na sve četiri dimenzije straha od smrti, što je u skladu s većinom ranijih istraživanja (npr. Cicirelli, 1999; Naderi \& Esmaili, 2009). Moguće objašnjenje je da su žene sklonije da pre priznaju da se plaše nego muškarci, u skladu sa rodnim ulogama.

Postoji nekoliko ograničenja ovog rada. Struktura uzorka ne odražava u potpunosti opštu populaciju, s obzirom na predominantnost mladih i studenata. Nadalje, pitanje o skorijoj smrti bliske osobe ne pruža uvid u uzrok smrti (npr. iznenadna smrt, hronična bolest, smrtonosna bolest) ni da li je ispitanik bio uključen u negu te osobe ili prisustvovao umiranju, što može uticati na njihovo poimanje smrti i sam strah od smrti. Uprkos pomenutim ograničenjima, rezultati ovog istraživanja potvrđuju validnost srpske adaptacije revidirane Collett-Lester skale straha od smrti, te podržavaju njenu dalju primenu u kroskulturnim i drugim istraživanjima. Ova skala može imati važnu primenu u ispitivanju straha od smrti u kriznim situacijama, kakva je npr. situacija izazvana COVID-19 pandemijom. Naime, u ovakvim situacijama je pojačan strah od smrti kako za sebe tako i za bližnje osobe (Schimmenti, Billieux, \& Starcevic, 2020), te bi upotreba CLFODS-R skale kao pouzdane i validne mere mogla doprineti uvidu u mehanizme javljanja straha od smrti a u cilju njegove redukcije. U narednim istraživanjima bi bilo poželjno u uzorak uključiti i ispitanike pomagačkih profesija koji rade sa osobama obolelim od koronavirusa ili sličnih virusa, sa starima ili osobama koje pate od teških bolesti, kako bi se ispitao njihov strah od smrti, te osmislile adekvatne edukacije u cilju redukovanja ovog straha i osnaživanja za pomoć pacijentima.

\section{Reference}

Abdel-Khalek, A. M. (2004). The Arabic Scale of Death Anxiety (asda): Its Development, Validation, and Results in Three Arab Countries. Death Studies, 28(5), 435-457. https://doi.org/10.1080/07481180490437572

Bath, D. (2010). Separation from loved ones in the fear of death. Death Studies, 34(5), 404-425. https://doi.org/10.1080/07481181003697639

Borges Hernández, M. A., \& De Miguel Negredo, A. (2020). Spanish Adaptation of the Multidimensional Fear of Death Scale. International Journal of Psychology \& Psychological Therapy, 20(1), 37-45.

Bužgová, R., \& Janíková, E. (2019). Czech Adaption of the Collett-Lester Fear of Death Scale in a Sample of Nursing Students. OMEGA - Journal of Death and Dying, 80(1), 20-34. 
Cai, W., Tang, Y., Wu, S., \& Li, H. (2017). Scale of Death Anxiety (SDA): Development and Validation. Frontiers in Psychology, 8. https://doi.org/10.3389/fpsyg.2017.00858

Carmel, S., \& Mutran, E. (1997). Wishes regarding the use of life-sustaining treatments among elderly persons in Israel: An explanatory model. Social Science \& Medicine, 45(11), 1715-1727. https://doi.org/10.1016/S0277-9536(97)00104-4

Cicirelli, V. G. (1999). Personality and demographic factors in older adults' fear of death. The Gerontologist, 39(5), 569-579. https://doi.org/10.1093/geront/39.5.569

Cheung, G. W., \& Rensvold, R. B. (2002). Evaluating goodness-of-fit indexes for testing measurement invariance. Structural Equation Modeling, 9(2), 233-255. https://doi. org/10.1207/S15328007SEM0902_5

Cohen, J. (1988). Statistical power analysis for the behavioralsciences (2nd ed.). Hillsdale, NJ: Erlbaum.

Collett, L.-J., \& Lester, D. (1969). The fear of death and the fear of dying. The Journal of Psychology, 72(2), 179-181. https://doi.org/10.1080/00223980.1969.10543496

Conte, H. R., Weiner, M. B., \& Plutchik, R. (1982). Measuring death anxiety: Conceptual, psychometric, and factor-analytic aspects. Journal of Personality and Social Psychology, 43(4), 775-785. https://doi.org/10.1037//0022-3514.43.4.775

Čolović, P., Smederevac, S., \& Mitrović, D. (2014). Velikih pet plus dva: validacija skraćene verzije. Primenjena psihologija, 7(3-1), 227-254. https://doi.org/10.19090/ pp.2014.3-1.227-254

Dadfar, M., Abdel-Khalek, A. M., Lester, D., \& Atef Vahid, M. K. (2017). The Psychometric parameters of the Farsi form of the Arabic Scale of Death Anxiety. The Scientific World Journal, Article ID 7468217. https://doi.org/10.1155/2017/7468217

Dinić, B. (2019). Principi psihološkog testiranja. Novi Sad, RS: Filozofski fakultet. Preuzeto sa http://digitalna.ff.uns.ac.rs/sadrzaj/2019/978-86-6065-540-2

Frazier, P. H., \& Foss-Goodman, D. (1988). Death anxiety and personality: Are they truly related? Omega: Journal of Death and Dying, 19(3), 265-274. https://doi. org/10.2190/141T-Q32F-LPPD-EY3W

Furnham, A., \& Buchanan, T. (2005). Personality, gender and self-perceived intelligence. Personality and Individual Differences, 39(3), 543-555. https://doi.org/10.1016/j. paid.2005.02.01

Galton, N. (2019). The Relationships Between Personality Traits, Death Attitudes, and Ageism (Unpublished thesis). Saint Paul University. Preuzeto sa http://dx.doi. org/10.20381/ruor-23418

Gravetter, F. J., \& Wallnau, L. B. (2014). Statistics for the behavioral sciences (9th ed.). Wadsworth, Belmon, CA: Jon-David Hague.

Lau, B. H., Wong, D. F. K., Fung, Y. L., Zhou, J., Chan, C. L. W., \& Chowm A. Y. M. (2018). Facing death alone or together? Investigating the interdependence of death anxiety, dysfunctional attitudes, and quality of life in patient-caregiver dyads confronting lung cancer. Psychooncology, 27(8), 2045-2051. https://doi.org/10.1002/pon.4773

Hoelter, J. W. (1979). Multidimensional treatment of fear of death. Journal of Consulting and Clinical Psychology, 47(5), 996-999. https://doi.org/10.1037//0022-006x.47.5.996

Lester, D. (1990). The Collett-Lester Fear of Death scale: The original version and a revision. 
Death Studies, 14(5), 451-468. https://doi.org/10.1080/07481189008252385

Lester, D., \& Abdel-Khalek, A. (2003). The Collett-Lester Fear of Death Scale: A correction. Death Studies, 27(1), 81-85. https://doi.org/10.1080/07481180302873

Lester, D., \& Templer, D. (1993). Death Anxiety Scales: A Dialogue: OMEGA - Journal of Death and Dying, 26(4), 239-253. https://doi.org/10.2190/F6GX-KXGX-PFR82HFD

Levin, R. (1990). A reexamination of the dimensionality of Death Anxiety. OMEGA Journal of Death and Dying, 20(4), 341-349. https://doi.org/10.2190/Y7R2-9KJCR943-KGGQ

Loo, R. (1984). Personality correlates of the Fear of Death and Dying Scale. Journal of Clinical Psychology, 40(1), 120-122. https://doi.org/10.1002/10974679(198401)40:1<120::aid-jclp2270400121>3.0.co;2-y

Mihić, Lj., Novović, Z., Čolović, P., \& Smederevac, S. (2014). Serbian adaptation of the Positive and Negative Affect Schedule (PANAS): Its facets and second-order structure. Psihologija, 47(4), 393-414. https://doi.org/10.2298/PSI1404393M

Mooney, D. C., \& O'Gorman, J. G. (2001). Construct validity of the revised Collett-Lester Fear of Death and Dying Scale. OMEGA - Journal of Death and Dying, 43(2), 157173. https://doi.org/10.2190/13PW-QPFY-B1PB-2AQA

Naderi, F., \& Esmaili, E. (2009). Collet-Lester Fear of Death Scale validation and genderbased comparison of death anxiety, suicide ideation and life satisfaction in university students. Journal of Applied Sciences, 9(18), 3308-3316. https://doi.org/10.3923/ jas.2009.3308.3316

Neimeyer, R. A. (1994). Death anxiety handbook: Research, instrumentation, and application. New York, NY: Taylor \& Francis.

Neimeyer, R. A., Moser, R. P., \& Wittkowski, J. (2003). Assessing attitudes toward dying and death: Psychometric considerations. Omega: Journal of Death and Dying, 47(1), 45-76. https://doi.org/10.2190/EP4R-TULM-W52G-L3EX

Normand, C. L., \& Mishara, B. L. (1992). The development of the concept of suicide in children. Omega: The Journal of Death and Dying, 25(3), 183-203. https://doi. org/10.2190/7TG9-NVG3-1RBJ-UDAH

Oral, R. (2017). The Relationship Between Five-Factor Model Personality Traits, Attachment Styles and Death Anxiety (Unpublished thesis). İstanbul Bilgi Üniversitesi. Preuzeto sa https://openaccess.bilgi.edu.tr/handle/11411/1052

Patton, J. F., \& Freitag, C. B. (1977). Correlational study of death anxiety, general anxiety and locus of control. Psychological Reports, 40(1), 51-54. https://doi.org/10.2466/ pr0.1977.40.1.51

$\mathrm{R}$ Core Team (2017). R: A language and environment for statistical computing. $\mathrm{R}$ Foundation for Statistical Computing, Vienna, Austria. http://www.R-project.org/.

Rosseel, Y. (2012). lavaan: An R Package for Structural Equation Modeling. Journal of Statistical Software, 48, 1-36. https://doi.org/10.18637/jss.v048.i02

Schermelleh-Engel, K., Moosbrugger, H., \& Müller, H. (2003). Evaluating the Fit of Structural Equation Models: Tests of Significance and Descriptive Goodness-of-Fit Measures. Methods of Psychological Research, 8(2), 23-74. 
Schimmenti, A., Billieux, J., \& Starcevic, V. (2020). The four horseman of fear: An integrated model of understanding fear experiences during the COVID-19 pandemic. Clinical Neuropsychiatry, 17(2), 41-45. https://doi.org/10.36131/ CN20200202

Sharif Nia, H. S., Lehto, R. H., Sharif, S. P., Mashrouteh, M., Goudarzian, A. H., Rahmatpour, P., Torkmandi, H., \& Yaghoobzadeh, A. (2019). A Cross-Cultural Evaluation of the Construct Validity of Templer's Death Anxiety Scale: A Systematic Review: OMEGA - Journal of Death and Dying. Online First. https://doi. org/10.1177/0030222819865407

Sharif Nia, H. S., Sharif, S. P., Koocher, G. P., Yaghoobzadeh, A., Haghdoost, A. A., Win, M. T. M., \& Soleimani, M. A. (2017). Psychometric Properties of the Death Anxiety Scale-Extended among Patients with End-Stage Renal Disease: OMEGA - Journal of Death and Dying, 80(3), 380-396. https://doi.org/10.1177/0030222817733220

Smith, D. K., Nehemkis, A. M., \& Charter, R. A. (1984). Fear of death, death attitudes, and religious conviction in the terminally Ill. The International Journal of Psychiatry in Medicine, 13(3), 221-232. https://doi.org/10.2190/19CN-7715-VLKQ-9F25

Templer, D. I. (1970). The construction and validation of a Death Anxiety Scale. The Journal of General Psychology, 82(2), 165-177. https://doi.org/10.1080/00221309 .1970 .9920634

Templer, D. I. (1976). Two factor theory of death anxiety: A note. Essence, 2, 91-92.

Templer, D. I., Awadalla, A., Al-Fayez, G., Frazee, J., Bassman, L., Connelly, H. J., Arikawa, H., \& Abdel-Khalek, A. M. (2006). Construction of a Death Anxiety Scale-Extended. OMEGA - Journal of Death and Dying, 53(3), 209-226. https://doi. org/10.2190/BQFP-9ULN-NULY-4JDR

Tomer, A. (1994). Death anxiety in adult life - theoretical perspectives. In A. Neimeyer (Ed.), Death anxiety handbook: Research, instrumentation, and application (pp. 3-30). New York, NY: Routledge.

Tomás-Sábado, J., \& Gómez-Benito, J. (2005). Construction and Validation of the Death Anxiety Inventory (DAI). European Journal of Psychological Assessment, 21(2), 108-114. https://doi.org/10.1027/1015-5759.21.2.108

Tomás-Sábado, J., Limonero, J. T., \& Abdel-Khalek, A. M. (2007). Spanish adaptation of the Collett-Lester fear of death scale. Death Studies, 31(3), 249-260. http://dx.doi. org/10.1080/07481180601152625

Watson, D., Clark, L., A. (1988). Development and validation of brief measures of positive and negative affect: The PANAS scales. Journal of Personality and Social Psychology, 54(6), 1063-1070. https://doi.org/10.1037//0022-3514.54.6.1063

Yang, S. C., \& Chen, S-F. (2009). The Study of Personal Constructs of Death and Fear of Death Among Taiwanese Adolescents. Death Studies, 33(10), 913-940. https://doi. org/10.1080/07481180903251687 


\title{
Kristina Petrović
}

\section{Iva Konc}

Bojana M. Dinićc ${ }^{4}$

Department of Psychology

Faculty of Philosophy

University of Novi Sad

\section{VALIDITY OF SERBIAN ADAPTATION OF THE COLLETT-LESTER FEAR OF DEATH SCALE-REVISED}

\begin{abstract}
The aim of this study was to validate the Serbian adaptation of the Collett-Lester Fear of Death Scale-Revised (CLFODS-R). On a sample comprised of 263 participants (66\% females), aged between 18 and 65 years, along with CLFODS-R, Big Five Plus Two-70 and PANAS were applied. Results support originally proposed factor structure of the scale, with differentiation of four dimensions: fear of death of self, fear of dying of self, fear of death of others, and fear of dying of others. All four dimensions significantly correlate with negative affect and neuroticism, while correlations with positive affect and extraversion are not significant, supporting the validity of the scale. Furthermore, females show higher scores on all dimensions, while older and participants with experience of the death of a close person show a lower fear of death in some of its aspects. The results suggested that the Serbian adaptation of CLFODS-R is a valid and reliable measure, and that it may find application in further examinations of fear of death.
\end{abstract}

Keywords: fear of death of self, fear of death of others, Collett-Lester Fear of Death Scale, factor analysis, validity

Primljeno: 27.01.2020.

Primljena korekcija: 19.06.2020. Prihvaćeno za objavljivanje: 20.06.2020.

\footnotetext{
${ }^{4}$ bojana.dinic@ff.uns.ac.rs
} 